\title{
Prediction of Student Performance in Academic and Military Learning Environment: Use of Multiple Linear Regression Predictive Model and Hypothesis Testing
}

\author{
Wasi Z. Khan ${ }^{1}$ \& Sarim Al Zubaidy ${ }^{2}$ \\ 1 Assistant Head, Quality Assurance Department, Military Technological College, PO Box 262 Post Code 111, \\ Muscat, Sultanate of Oman \\ ${ }^{2}$ President, University of Trinidad and Tobago, O’Meara Campus, Trinidad and Tobago \\ Correspondence: Wasi Z. Khan, Assistant Head, Quality Assurance Department, Military Technological College, PO \\ Box 262 Post Code 111, Muscat, Sultanate of Oman
}

Received: June 14, 2017

Accepted: August 9, 2017

Online Published: August 17, 2017

doi:10.5430/ijhe.v6n4p152

URL: https://doi.org/10.5430/ijhe.v6n4p152

\begin{abstract}
The variance in students' academic performance in a civilian institute and in a military technological institute could be linked to the environment of the competition available to the students. The magnitude of talent, domain of skills and volume of efforts students put are identical in both type of institutes. The significant factor is the physical training, students undergo in a military college. It is important to couple the dominating factor which is academic perceivable effort under a different environment with each students learning capability. This paper determine whether there is a relationship between students' performance and influencing factors like academic aptitude, military or physical training, and the time spent on training need analysis (TNA) modules. A sample of 242 first year- undergraduate students from four different engineering programs (Marine, System, Civil, and Aeronautical) at Military College was used to explore this relationship. The multiple regression model used for predicting the students' performance is adequate for independent variables of aptitude test score, time spent in physical training, and time spent in TNA modules. The values of $\mathrm{R}^{2}$ indicate that at least one of the predictor variables contributes to information for the prediction of the students' performance. The model makes it possible to predict moderately the possibility of attrition in engineering program. This study verifies that military academy has a very defined and directed core engineering course load and TNA course load which every student must take. Therefore, choice of specific discipline have less impact than at civilian institutions. The early detection of students at academic risk is a useful instrument that can help to design mentoring strategies right from the end of admission process.
\end{abstract}

Keywords: Student's performance, Multiple linear regression, Hypothesis testing, Military learning environment

\section{Introduction}

A common observation shared by educators and researchers is that the students' performance is dependent on curricular and extra-curricular activities. The authors of this paper have experienced variance in performance while teaching in both civilian institutes and in military technological institutes. The performance could be linked to the environment of competition available to the students. There is no doubt about the magnitude of talent, domain of skills and the volume of effort students put in, which is identical in both type of institutes. However, the significant factor is the physical training students undergo in a military college. Often educators are unable to predict success of a student even if they know the amount of effort a student is putting in, and the dedication he/she demonstrates (Eric, 2012). It is important to couple the dominating factor, which is academic perceivable effort, under a different environment with each students learning capability.

In athletics this variance is easily understood. The individual who works hard in developing new skills or capabilities realizes the greatest success (Ericsson et al. 1993). According to Malcom Gladwell (2008) it takes 10,000 hours of practice to fully master a skill and become an expert, Whereas Peter Doskoch (2005) presents a 10 year rule in perseverance of a talent and achievement of significant objectives. It is evident that professional will and workmanlike diligence are the attributes for success in any career. 
The instructor has limited time and resources to put into each students desires for success. It is up to the student to determine how he/she benefits himself/herself from these resources. It is also up to the institute to set up the admission criteria and make decisions typically based on merit, high school performance and standard entrance tests. The admission process is based on known and trusted predictors, hence the results can be forecasted. The resource allocation decision is another predictor that measures outcome alignment with the input, especially for freshman class'.

There are many other factors that can influence students' performance, such as gender (does not apply at Military college under study as all students were male), high school background, academic aptitude, military or physical training, socio-demographic variables, and emotional \& psychosocial characteristics.

The purpose of this study is to determine whether there is a relationship between students' performance and influencing factors like aptitude test, time spent on physical training, and time spent on TNA modules; to explore the relationship between educational aptitude and academic performance in a sample of 242 first year - undergraduate students from four different engineering programs (Marine, System, Civil, and Aeronautical) at a military college. The early detection of students who are vulnerable to suffering academic failure is useful in helping to design mentoring strategies right from the end of admission process. This study is based on published empirical-observational data and its comparison with available data of the MTC students' academic performance during first year of their B. Eng. program. The novelty of the proposed method of this study is that it verifies the impact of different environment in a military academy on academic performance due to academic load. In a military academy with a core engineering course load every student must take TNA course load too. Therefore, choice of specific discipline has less impact than at civilian institutions.

\section{Hypotheses}

The hypotheses of this study are:

$\mathrm{H}_{1}$ : There is an association between academic aptitude tests and academic performance.

$\mathrm{H}_{2}$ : There is an association between academic performance and time spent in physical training.

$\mathrm{H}_{3}$ : In a military academy there is a stronger association between magnitude of physical training and academic performance.

There are a number of theories presented by researchers focused on students' performance and its relation to their decision to dropout (Bean and Metzner's Student Attrition Model, 1985), and also to the interactions of the students with the academic institution (Tinto's Student Integration Model, 1975). A review of published studies at an international level suggests that independent variables like gender, high school background, academic aptitude, military or physical training, socio-demographic circumstances, and emotional \& psychosocial characteristics need to be tested under standardized hypothesis testing scores.

\section{Insignificant Variables}

The use of linear regression between factors like age, sex, socio-demographic origin, socio-economic characteristics; and academic performance conducted over 5000 undergraduate university students by Betts and Morell (1999) indicates that there is not a significant relationship. Similarly in another study Lorenzano \& Ferraro (2003) used a sample of 516 undergraduate students who passed a number of subjects during the first semester and found that factors like age, sex, socio-demographic origin, and socio- economic characteristics are insignificant. However, the study conducted by Porto and DiGresia (2004) based on voluntary survey of 4,676 students of economic science revealed that factors like sex and age are less significant than others.

\section{Significant Variables}

\subsection{Academic Aptitude or Entrance Tests}

Noble and Sawyer (1997) used statistical theoretical analysis for measuring academic attitude and reported that a linear relationship between aptitude tests and academic results exists. Medina \& Tapia (2004) used a sample of 120 students admitted through entrance tests (ATE) and 87 students without (under direct entry into bachelor program) at the University of Chile, and reported that ATE showed a better academic performance. Gallacher (2005) analyzed the predictive power of aptitude tests by using 91 freshman students and 90 graduates and concluded that aptitude tests are a useful tool even when the predictions derived from them are far from perfect. 


\subsection{High School Background}

Eno, D et al (1999) used a sample of 12,000 undergraduate students of Virginia Tech University; Pike and Saupe (2002) used a sample of 8,764 undergraduate students; Beguet, et al (2001) used a sample of 324 undergraduate students between two cohorts; and Foio and Espinola (2004) used a sample of 4632 undergraduate students during the first year at the university, reported that a good performance in high school results predicts a good performance at the university. However, the ratio of high school GPA to university GPA was 7.67/5.69 which correspond to higher academic activity at university.

\subsection{Variables in Military Studies}

Castro Solano \& Casullo (2002) used a sample of 363 students from a military academy made up of $89 \%$ of male and $11 \%$ female, all 18-22 years old, for analysis to identify and determine variables of high and low performing students. They concluded that most successful students show an assertive and ambitious trend with lower acceptance of standards. They captured concrete, tangible and observable data, less focused on details and more related to a large number of students. Eric Buller's (2012) findings on the relationship between grit and academic, military and physical training at US military academy indicated that the relationship, though statistically significant, is not particularly strong, and therefore not a good measurement of success. He reported that regression analysis indicates that grit provides a statistically significant explanation for variability in factors like aptitude tests and academic achievements. The effect of age, sex, and ethnicity were insignificant, and therefore not a predictor for success at the military academy.

\section{Methodology}

The multiple linear regression model presented by Shakil (2008 and 2009), and hypothesis testing undertaken by Angela et al. (2013) is used in this study for a sample of 242 students. The constraints associated with our data are:

(a) There is invariability in high school background, hence assumed constant.

(b) There is no standardized assessment for physical training, hence time spent in physical training is considered as a dependent variable.

(c) Lack of variability in nature and type of physical training activity.

The predictor or the response variable $\mathrm{Y}$ in the following multiple linear regression equation

$$
Y=\beta_{\mathrm{o}}+\beta_{1} \mathrm{X}_{1}+\beta_{2} \mathrm{X}_{2}+\beta_{3} \mathrm{X}_{3}+\varepsilon
$$

represents the academic performance. The independent variables $X_{1}, X_{2}$, and $X_{3}$ are the examination results, aptitude test results, and time spent in physical training respectively. All five assumptions used by Shakil (2009 and 2001) and Shakil and Singh (2001) considered applicable to our data. The study made at an Argentinian military academy is more relevant (Castro, 2002) in objectivity as it was to identify the factors associated to academic and military performance of undergraduate students.

\subsection{Participants}

A non-random sample of 242 first year undergraduate students of a 2014 cohort belonging to Aeronautical, Civil, Marine, and Systems Bachelor of Engineering (B. Engg.) and Diploma in Higher Education (DipHE) program were chosen. The socioeconomic level of sampled students is homogeneous, and a majority of them belonged to medium and medium to high income sectors of society.

\subsection{Instrument of Data Analysis}

The results of the academic aptitude test is applied to students after being admitted in the military institute. The aptitude tests consist of the IELTS score, Mathematics, Science, elements of mechanical reasoning and numerical ability. The observational analysis of the faculty of the general foundation program was considered as highly reliable and sufficiently intercorrelated within the array of aptitude tests.

The details of military activities collected from the military department at college, were translated into time dependent physical training. This instrument showed a good validity when compared with the physical training program of other military academies in the world.

The results of course work (30-40\%) and final examinations (60-70\%) of the students' in their first academic year was collected from the examination department and used to measure the academic performance. The similar approach has been used worldwide in defining the cognitive profile for each student. The attrition in four engineering departments was measured in terms of number of students dropped out during the year. The students dropped out 
from Aeronautical Engineering, Civil Engineering, Marine Engineering, and Systems Engineering was 23, 20, 20, and 25 respectively.

\section{Procedure}

For analysis of the aptitude test, a general linear model of Searle (1971) was used. The selection of the final model was based on the Akaike Information Criterion (AIC) Statistics (Sakamoto et al. 1986) in which the parameters selected have a p-value less than 0.05 . The multiple regressions were constructed to analyze the relationship of each dependent variable with academic performance for students of four engineering departments. The coding technique was used for students who were dropping-out.

\section{Interpreting the Results and Discussion}

The average and standard deviation of the examination results of common engineering modules (Engineering Mathematics-I, Engineering Science, Engineering Material \& Hardware, Electrical Engineering Principles, Introduction to Electrical Engineering, Introduction to Civil Engineering, and Engineering System Design-I) is presented in table 1 . The grade distribution of the same modules is shown in table 2 . The final examination grade distribution of these engineering modules are shown in tables 3-8. The table 9 presents the distribution of cohort among engineering departments.

Table 1. Average and standard deviation of exam results by module

\begin{tabular}{lccc}
\hline \multicolumn{1}{c}{ Module } & Average & Standard deviation & Sample size (N) \\
\hline Engineering Maths-1 & 58.6 & 14.75 & 242 \\
Engineering Science & 66.8 & 10.84 & 242 \\
Eng. Materials \& Hardware & 47.1 & 11.88 & 242 \\
Electrical Eng. Principles & 61.0 & 9.92 & 242 \\
Intro. to Electrical Eng. & 60.8 & 12.55 & 242 \\
Intro. to Civil Engineering & 68.6 & 6.74 & 32 \\
Eng. System Design-1 & 72.7 & 11.32 & 242 \\
Overall & 62.2 & 11.14 & $\mathrm{NA}$ \\
\hline
\end{tabular}

Table 2. Grade distribution $(\%)^{1}$ in common engineering modules

\begin{tabular}{lccccc}
\hline \multicolumn{1}{c}{ Module } & $\mathrm{A}$ & $\mathrm{B}$ & $\mathrm{C}$ & $\mathrm{D}$ & $\mathrm{F}$ \\
\hline Engineering Maths-1 & 25.6 & 21.1 & 16.9 & 0.4 & 36.0 \\
Engineering Science & 38.8 & 34.7 & 0.40 & 0.0 & 26.0 \\
Eng. Materials \& Hardware & 5.0 & 9.5 & 32.6 & 3.3 & 49.6 \\
Electrical Eng. Principles & 22.7 & 34.7 & 22.7 & 0.4 & 19.4 \\
Intro. To Electrical Eng. & 24.8 & 39.5 & 22.4 & 1.0 & 12.4 \\
Intro. To Civil Engineering & 59.4 & 34.4 & 0.0 & 0.0 & 6.3 \\
Eng. System Design-1 & 70.2 & 14.5 & 2.9 & 0.0 & 12.4 \\
Overall & 35.2 & 26.9 & 14.0 & 0.7 & 23.1 \\
\hline
\end{tabular}

1. $\mathrm{A}=>70 \% ; \mathrm{B}=60-69 \% ; \mathrm{C}=50-59 \% ; \mathrm{D}=40-49 \% ;$ and $\mathrm{F}=<40 \%$ 
Table 3. Final examination grade distribution of Engineering Mathematics

\begin{tabular}{llllll}
\hline $\begin{array}{l}\text { Performance } \\
\text { (Grade) }\end{array}$ & $\begin{array}{l}\text { Aeronautical } \\
\text { Engineering }\end{array}$ & $\begin{array}{l}\text { Civil } \\
\text { Engineering }\end{array}$ & $\begin{array}{l}\text { Marine } \\
\text { Engineering }\end{array}$ & $\begin{array}{l}\text { Systems } \\
\text { Engineering }\end{array}$ & Average \\
\hline F & $9 \%$ & $44 \%$ & $54 \%$ & $48 \%$ & $38.75 \%$ \\
D & $15 \%$ & $28 \%$ & $26 \%$ & $26 \%$ & $23.75 \%$ \\
C & $21 \%$ & $19 \%$ & $12 \%$ & $11 \%$ & $15.75 \%$ \\
B & $19 \%$ & $9 \%$ & $3 \%$ & $6 \%$ & $09.25 \%$ \\
A & $36 \%$ & $0 \%$ & $6 \%$ & $8 \%$ & $12.50 \%$ \\
\hline
\end{tabular}

Table 4. Final examination grade distribution of Engineering Science

\begin{tabular}{llllll}
\hline Marks & $\begin{array}{l}\text { Aeronautical } \\
\text { Engineering }\end{array}$ & $\begin{array}{l}\text { Civil } \\
\text { Engineering }\end{array}$ & $\begin{array}{l}\text { Marine } \\
\text { Engineering }\end{array}$ & $\begin{array}{l}\text { Systems } \\
\text { Engineering }\end{array}$ & Average \\
\hline F & $10 \%$ & $59 \%$ & $15 \%$ & $31 \%$ & $28.75 \%$ \\
D & $10 \%$ & $19 \%$ & $32 \%$ & $32 \%$ & $23.25 \%$ \\
C & $12 \%$ & $19 \%$ & $24 \%$ & $16 \%$ & $17.75 \%$ \\
B & $22 \%$ & $3 \%$ & $6 \%$ & $11 \%$ & $10.50 \%$ \\
A & $46 \%$ & $0 \%$ & $24 \%$ & $9 \%$ & $19.75 \%$ \\
\hline
\end{tabular}

Table 5. Final examination grade distribution of Engineering Materials and Hardware

\begin{tabular}{llllll}
\hline $\begin{array}{l}\text { Performance } \\
\text { (Grade) }\end{array}$ & $\begin{array}{l}\text { Aeronautical } \\
\text { Engineering }\end{array}$ & $\begin{array}{l}\text { Civil } \\
\text { Engineering }\end{array}$ & $\begin{array}{l}\text { Marine } \\
\text { Engineering }\end{array}$ & $\begin{array}{l}\text { Systems } \\
\text { Engineering }\end{array}$ & Average \\
\hline F & $10 \%$ & $59 \%$ & $15 \%$ & $31 \%$ & $28.75 \%$ \\
D & $10 \%$ & $19 \%$ & $32 \%$ & $32 \%$ & $23.25 \%$ \\
C & $12 \%$ & $19 \%$ & $24 \%$ & $16 \%$ & $17.75 \%$ \\
B & $22 \%$ & $3 \%$ & $6 \%$ & $11 \%$ & $10.50 \%$ \\
A & $56 \%$ & $0 \%$ & $24 \%$ & $9 \%$ & $22.25 \%$ \\
\hline
\end{tabular}

Table 6. Final examination grade distribution of Electrical Engineering Principles.

\begin{tabular}{llllll}
\hline \multirow{2}{*}{ Marks } & $\begin{array}{l}\text { Aeronautical } \\
\text { Engineering }\end{array}$ & $\begin{array}{l}\text { Civil } \\
\text { Engineering }\end{array}$ & $\begin{array}{l}\text { Marine } \\
\text { Engineering }\end{array}$ & $\begin{array}{l}\text { Systems } \\
\text { Engineering }\end{array}$ & Average \\
\hline F & $9 \%$ & $22 \%$ & $21 \%$ & $26 \%$ & $19.50 \%$ \\
D & $27 \%$ & $13 \%$ & $35 \%$ & $36 \%$ & $27.75 \%$ \\
C & $26 \%$ & $19 \%$ & $24 \%$ & $21 \%$ & $22.50 \%$ \\
B & $19 \%$ & $19 \%$ & $15 \%$ & $8 \%$ & $15.25 \%$ \\
A & $19 \%$ & $28 \%$ & $6 \%$ & $8 \%$ & $15.25 \%$ \\
\hline
\end{tabular}


Table 7. Final examination grade distribution of Introduction to Electrical Engineering.

\begin{tabular}{lllll}
\hline $\begin{array}{l}\text { Performance } \\
\text { (Grade) }\end{array}$ & $\begin{array}{l}\text { Aeronautical } \\
\text { Engineering }\end{array}$ & $\begin{array}{l}\text { Marine } \\
\text { Engineering }\end{array}$ & $\begin{array}{l}\text { Systems } \\
\text { Engineering }\end{array}$ & Average \\
\hline F & $10 \%$ & $6 \%$ & $15 \%$ & $10.33 \%$ \\
D & $15 \%$ & $29 \%$ & $29 \%$ & $24.33 \%$ \\
C & $28 \%$ & $15 \%$ & $29 \%$ & $24.00 \%$ \\
B & $27 \%$ & $26 \%$ & $22 \%$ & $25.00 \%$ \\
A & $20 \%$ & $24 \%$ & $5 \%$ & $16.34 \%$
\end{tabular}

Table 8. Final examination grade distribution of Engineering Systems Design 1.

\begin{tabular}{llllll}
\hline $\begin{array}{l}\text { Performance } \\
\text { (Grade) }\end{array}$ & $\begin{array}{l}\text { Aeronautical } \\
\text { Engineering }\end{array}$ & $\begin{array}{l}\text { Civil } \\
\text { Engineering }\end{array}$ & $\begin{array}{l}\text { Marine } \\
\text { Engineering }\end{array}$ & $\begin{array}{l}\text { Systems } \\
\text { Engineering }\end{array}$ & Average \\
\hline F & $0 \%$ & $15 \%$ & $2 \%$ & $4 \%$ & $05.25 \%$ \\
D & $0 \%$ & $7 \%$ & $21 \%$ & $0 \%$ & $07.00 \%$ \\
C & $9 \%$ & $0 \%$ & $18 \%$ & $17 \%$ & $11.00 \%$ \\
B & $0 \%$ & $0 \%$ & $26 \%$ & $19 \%$ & $11.25 \%$ \\
A & $91 \%$ & $78 \%$ & $33 \%$ & $60 \%$ & $65.50 \%$ \\
\hline
\end{tabular}

Table 9. Distribution of cohort among engineering departments.

\begin{tabular}{lc}
\hline Department & Number of students \\
\hline Aeronautical Engineering & 78 \\
Civil Engineering & 32 \\
Marine Engineering & 34 \\
Systems Engineering & 98 \\
Grand Total & 242 \\
\hline
\end{tabular}

The coefficient of determination $\left(\mathrm{R}^{2}\right)$ values obtained for each engineering program shows that the academic performance is explained by the given independent variables. The most suitable regression model dictates that aptitude test does not relates significantly to the academic performance. The Excel multiple regression summary output for regression statistics and analysis of variance is given in table 10. 
Table 10. The summary output of final examination grades data for independent variables

\begin{tabular}{lc}
\hline \multicolumn{2}{c}{ Regression Statistics } \\
\hline Multiple R & 0.984908 \\
R Square & 0.970044 \\
Adjusted R Square & 0.440088 \\
Standard Error & 0.011712 \\
Observations & 5 \\
\hline
\end{tabular}

ANOVA

\begin{tabular}{lccccc}
\hline & $d f$ & $S S$ & $M S$ & $F$ & Significance $F$ \\
\hline Regression & 3 & 0.008883304 & 0.00296 & 32.3821 & 0.128302193 \\
Residual & 2 & 0.000274328 & 0.00014 & & \\
Total & 5 & 0.009157632 & & & \\
\hline
\end{tabular}

\begin{tabular}{lcccccc}
\hline & Coefficients & Standard Error & $t$ Stat & P-value & Lower 95\% & Upper 95\% \\
\hline Intercept & -1.830396 & 0.578526936 & -3.16389 & 0.08705 & -4.31959658 & 0.658804423 \\
X1 & 2.080784 & 0.733415115 & 2.83712 & 0.10503 & -1.074846235 & 5.236414862 \\
X2 & 0.080514 & 0.014107521 & 5.70715 & 0.02936 & 0.01981396 & 0.141213491 \\
X3 & 0 & 0 & 65535 & 0 & 0 & 0
\end{tabular}

Based on table 10, the regression equation, with coefficient values for each independent variable, and the response variable ("Y" represent the academic performance) is:

$$
\begin{aligned}
& \mathrm{Y}=-1.8303+2.0808 \mathrm{X}_{1}+0.0805 \mathrm{X}_{2}+0.0 \mathrm{X}_{3} . \\
& \mathrm{S}=11.14, \quad \mathrm{R}^{2}=97 \%, \quad \mathrm{R}^{2}{ }_{\text {(adj) }}=44 \%
\end{aligned}
$$

From the ANOVA in table 10, we observe that the P-value is $0-0.10$, which implies that the model estimation is significant at a significance level of 0.05 . The $P$-values for the estimated coefficients of $X_{2}$ and $X_{3}$ are 0.029 and 0.0 respectively, indicating that both are significantly related to predictor variable. However, the $\mathrm{P}$-value of $\mathrm{X}_{1}$ is 0.105 , indicating that probably it is not related to $\mathrm{Y}$. The coefficient of multiple determination $\left(\mathrm{R}^{2}\right)$ shows that only $97 \%$ of the total variations of the $\mathrm{Y}$ values about their mean are explainable by the predictor variable, indicating moderate goodness of fit of the multiple regression model and the model has adequate predictive ability.

The smallest value of coefficient of variation $(\mathrm{CV})$ is another measure of model's suitability of model in rendering precise predictions. The $\mathrm{CV}$ value of 0.179 indicates that standard deviation of the students' performance is only $17.9 \%$ of their mean.

\section{Hypothesis testing by t- distribution}

This hypothesis can be tested using a t- distribution test statistic given by:

$$
\mathrm{t}=\left(\beta_{\mathrm{i}}-0\right) / \operatorname{Se}\left(\beta_{\mathrm{i}}\right)
$$

Assuming that the variation of observations about the line are normal, we can use $(1-\alpha)=100 \%$ confidence limits for critical values of $\beta_{\mathrm{i}}$ by calculating

$$
\beta_{\mathrm{i}} \pm \mathrm{t}\{\mathrm{n}-2,1-(\alpha / 2)\} . \text { Se }\left(\beta_{\mathrm{i}}\right)
$$

Where $\{n-2,1-(\alpha / 2)\}$ is the $(1-\alpha)=100 \%$ percentage points for $\mathrm{t}$ - distribution, with $\mathrm{n}-2$ degree of freedom

\section{Test of significance for each independent variable}

$\mathrm{H}_{\mathrm{o}}: \quad \beta \mathrm{i}=0$ versus $\mathrm{H}_{1} \neq 0$ 
Table 11.

\begin{tabular}{lllll}
\hline $\begin{array}{l}\text { Null } \\
\text { Hypothesis }\end{array}$ & $\begin{array}{l}\mathrm{t} \text { - critical values }(3, \\
0.975)\end{array}$ & $|\mathrm{t}|$ & Inference & Conclusion \\
\hline $\mathrm{H}_{\mathrm{o}}: \beta_{1}=0$ & 3.182 & 2.83 & $\begin{array}{l}\text { Do not } \\
\text { reject } \mathrm{H}_{\mathrm{o}} \\
\text { Reject } \mathrm{H}_{\mathrm{o}}\end{array}$ & $\begin{array}{l}\text { In the presence of } \mathrm{X}_{2} \text { and } \mathrm{X}_{3} ; \mathrm{X}_{1} \text {, is not } \\
\text { a good predictor of } \mathrm{Y} .\end{array}$ \\
$\mathrm{H}_{\mathrm{o}}: \beta_{2}=0$ & 3.182 & 5.70 & $\begin{array}{l}\text { In the presence of } \mathrm{X}_{1} \text { and } \mathrm{X}_{3} ; \mathrm{X}_{2} \text {, is a } \\
\text { good predictor of } \mathrm{Y} .\end{array}$ \\
$\mathrm{H}_{\mathrm{o}}: \beta_{3}=0$ & 3.182 & 0.0 & $\begin{array}{l}\text { Do not } \\
\text { reject } \mathrm{H}_{\mathrm{o}}\end{array}$ & $\begin{array}{l}\text { In the presence of } \mathrm{X}_{1} \text { and } \mathrm{X}_{2}, \mathrm{X}_{3}, \text { is a } \\
\text { poor predictor of } \mathrm{Y} .\end{array}$ \\
\hline
\end{tabular}

The absolute values of "t" shown in table 11 is taken from table 10 . However, the t-critical values in table 11 are calculated by taking significance level 0.05 . The Inference and conclusion in table 11 are drawn by comparing the absolute value of " $\mathrm{t}$ " with $\mathrm{t}$-critical values. Hence is the test of null hypothesis $\left(\mathrm{H}_{\mathrm{o}}\right)$ against alternative or research hypothesis $\left(\mathrm{H}_{1}\right)$.

\section{Hypothesis testing by $\mathrm{F}$ - test}

$\mathrm{H}_{\mathrm{o}}: \beta_{1}=\beta_{2}=\beta_{3}=0$ (regression is insignificant) versus $\mathrm{H}_{1}$ : at least one of $\beta_{\mathrm{i}}$ 's $\neq 0$ (regression is significant).

$$
\mathrm{F}=\mathrm{MS}_{\mathrm{reg}} / \mathrm{MS}_{\mathrm{res}}=21.61
$$

The hypotheses can also be tested using the F-statistics with the following decision rule.

Reject $\mathrm{H}_{\mathrm{o}}$ if $|\mathrm{t}|>\{\mathrm{n}-2,1-(\alpha / 2)\}$. The $\mathrm{t}$ - statistics values for different $\beta_{\mathrm{i}}$ 's are based on summary output of the multiple linear regressions are shown in table 10. By comparing $F$ values with the critical values of $F$ at given degree of freedom and 1- $\alpha$ values, we reject $H_{o}$ that is the regression is insignificant. Therefore, the overall regression is statistically significant. Hence, it can be concluded that at least one of the predictor variable contributes information for the prediction of $\mathrm{Y}$. According to the best regression model for each independent variable, the time spent in physical training $(p<0.0293)$ and time spent in TNA modules $(p<0.0)$ are related significantly to students' academic performance. Whereas, test results score in aptitude test is insignificant in a military college environment.

\section{Conclusions}

The multiple regression model used for predicting the students' performance is adequate for independent variables of aptitude test score $\left(\mathrm{X}_{2}\right)$, time spent in physical training $\left(\mathrm{X}_{3}\right)$, and time spent in TNA modules. The values of $\mathrm{R}^{2}$ indicate that at least one of the predictor variables contributes to information for the prediction of the students' performance. The rejection of null hypothesis indicates that the regression is not significant and the overall regression is statistically significant. The time spent in physical training is an instrument that allows estimating students' performance in the first academic year of an undergraduate program. The model makes it possible to predict moderately the possibility of attrition in engineering program. These results slightly differ from the findings of Eric Buller (2012) who found that academic achievement (in terms of GPA) also depend on chosen major, and general education requirements of the specific campuses. This study verifies that military academy has a very defined and directed core engineering course load plus TNA course load which every student must take. Therefore, choice of specific discipline has less impact than at civilian institutions. This study also verifies that the impact of military training environment does make a difference in academic performance.

\section{References}

Angela C., Maria P., Belen M., \& Angel C. (2013). Predicting academic performance and attrition in undergraduate students, Liberabit: Lima (Peru), 19(1), 101-112; (ISSN: 2223-7666 (digital) \& ISSN: 1729-4827 (Print)).

Bean, J., \& Metzner, B. (1985). A conceptual model of nontraditional undergraduate student attrition, Review of Educational Research, 55(4), 485-540. https://doi.org/10.3102/00346543055004485.

Beguet, B., Kohan, N. Castro Solano \& Renault. (2001). Factores que intervienen en le rendimiento acdemico de los estudiantes de psicologia y psicopedagogia, Revista Cientifica de la Direccion de Evaluacion y Acreditacion de la Secretaria General de la Universidad del Salvador-USAL, I(1), 1-18. www.salvador.edu.ar/uc4-pub-01-1-1-04.htm.

Betts, J., \& Morell, D. (1999). The determinant of undergraduate grade point average: The relative importance of family background, high school resources, and peer group effects, The Journal of Human Resources, 34(2), 268-293. https://doi.org/10.2307/146346. 
Castro Solano, A., \& Casullo, M. (2002). Preditors del rendimiento academic military de cadets argentinos, Anales de Psicologia, 18(2), 249-257.

Doskoch, P. (2005). The winning Edge, Psychology Today.

Eno, D., McLaughlin, G., Sheldon, P. \& Brozovsky, P. (1999). Predicting freshman success based on high school record and other measures, AIR Professional File, 72, 1-12. www3.airweb.org/page.asp? page $=73 \&$ apppage $=85 \& \mathrm{id}=72$.

Eric F. B. (2012). The relationship between Grit and Academic, Military and Physical Performance at the United States Military Academy, PhD thesis, University of Kansas.

Ericsson, K., Krampe, R., \& Tesch-Romer, C. (1993). The role of deliberate practice in the acquisition of expert performance, Psychological Review, 100(3), 363-406. https://doi.org/10.1037/0033-295X.100.3.363.

Foio, M., \& Espinola, A. (2004). Seguimiento academic de los ingresantes 2002, Documentos de la Secretaria de Planificacion de le Universidad National del Nordeste. www.eluniversitario.unne.edu..ar/2004/44/pagina/Inform\%20Completo.pdf.

Gallacher, M. (2005). Predicting academic performance, Document of Universidad del CEMA. www.ucema.edu.ar/.../documentos/312.pdf.

Gladwell, M., (2008). Outliers: the story of success, New York, Little Brown Company.

Lorenzano, C., and Ferraro, M. (2003). Perfil de los ingresantes de la Universidad Nacional de Tres de Feberro: rendimiento y posibles cause del fracaso academico, Paper presented at the II National Congress in Educational Research.

Medina, N., \& Tapia, A. (2004). La admission a la de Kienesiologia de la Universidad de Chile via bachillerato y via Prueba de Aptitude Academia: Sistemas de ingreso como predictors del rendimiento acdemico, Thesis submitted for Kinesiology degree. Facultad de Medicina, Universidad de Chile. www.cybertesis.cl/tesis/uchile/2004/medina_n/sources/medina_n.pdf.

Noble, J., \& Sawyer, R. (1997). Alternative methods for validating admissions and course placement criteria, AIR Professional File, 63, 1-12. www3.airweb.org/page.asp?page=73\&apppage=85\&id=63.

Pike, G. \& Saupe, J. (2002). Does high school matter? An analysis of three methods of predicting first-year grades, Research in Higher Education, 43(2), 187-207. https://doi.org/10.1023/A:1014419724092.

Porto, A., \& Di Gresia, L. (2004). Rendimiento de estudiantes universitarios y sus determinantes, Revista de Economia y Estadistica XLII, 94-113.

Sakamoto, Y., Ishiguro, M., \& Kitagawa, G. (1986). Akaike Information Criterion Statistics, Dordlecht/Tokyo: D-Reidel Publishing Company.

Searle, S. (1971). Linear models, New York: J. Willey \& Sons.

Shakil M. (2009). A multiple linear regression model to predict the student's final grade in a mathematics class, Bioresource Technology, 101(13), 4971-4979. www.academia.edu/11892569/A_Multiple_Linear_Regression_Model_to_Predict_the_Students_Final_Grade_i n_a_Mathematics_Class.

Shakil, M. (2008). A Multiple Linear Regression Model to Predict the Student's Final Grade in a Mathematics Class, Polygon, Vol. II, (A Web-Based, Multi-Disciplinary Publication of Miami Dade College, Hialeah Campus, Fl., U.S.A.).

Shakil M. (2001). Fitting a linear model to predict the college GPA of matriculating freshmen based on their college entrance verbal and mathematics test scores, A data analysis I computer project, University Park, Florida: Department of Statistics, Florida International University.

Shakil, M., \& Singh, J. N. (2001). Fitting Some Regression Models to predict the students' Final examination scores in trigonometry class at Florida International University, Paper presented at the Gold Coast Meeting of American Mathematical Association, Miami Dade Community College, Wolfson Campus, Miami, Florida, USA, October 5-6, 2001.

Tinto, V. (1975). Dropout of higher education. A theoretical synthesis of recent research, Review of Educational Research, 45(1), 89-125. https://doi.org/10.3102/00346543045001089 